\title{
PERAN SPIRITUALITAS DAN KEPUASAN HIDUP TERHADAP KUALITAS HIDUP PADA WIRAUSAHAWAN MUDA
}

\author{
Irfan Aulia Syaiful, Ririn Nur Abdiah Bahar \\ Fakultas Psikologi, Universitas Mercu Buana Jakarta. Jalan Meruya Selatan No 1, \\ Kembangan, Jakarta Barat 11650 \\ irfan.aulia@mercubuana.ac.id; ririn.bahar21@gmail.com
}

\begin{abstract}
Everyone hope they have a good quality of life and also have standard on own quality of life, including entrepreneurs. Quality of life can cover all aspects of life, like spirituality and life satisfaction. This study aimed to determine whether there is an influence of spirituality and life satisfaction on quality of life of young entrepreneurs. The subject was 384 of young entrepreneurs spread almost all over in Indonesian that aged 20-40 years old. Data was collected using Questionnaire that was adapted with process one way translation, including Spirituality Scale developed by Delaney, Satisfaction with Life Scale (SWLS) developed by Diener, Emmons, Larsen, \& Griffin, and WHOQOL-BREF developed by WHO, that was distributed through a group of young entrepreneurs such as Indonesian Young Entrepreneurs Association, Muslim Indonesia Entrepreneur Network, and Junior Chamber International Indonesia. Multiple regression technique was used to analyze the data. The results concluded that spirituality and life satisfaction have a significant effect to quality of life on young entrepreneurs.
\end{abstract}

Keywords: life satisfaction, quality of life, spirituality, young entrepreneurs.

\begin{abstract}
Abstrak
Setiap orang pasti menginginkan kualitas hidup yang baik dan juga memiliki standar tersendiri mengenai kualitas hidupnya, begitu pun dengan wirausahawan. Kualitas hidup dapat mencakup semua aspek kehidupan yang tidak terlepas dari unsur spiritualitas dan kepuasan hidup. Penelitian ini bertujuan untuk mengetahui apakah ada hubungan spiritualitas dan kepuasan hidup (life satisfaction) terhadap kualitas hidup (quality of life) pada wirausahawan muda. Subjek penelitian ini adalah wirausahawan muda yang tersebar hampir di seluruh Indonesia yang berusia 20-40 tahun sebanyak 384 subjek. Alat ukur yang digunakan adalah kuesioner yang diadaptasi dengan proses one way translation, diantaranya Spirituality Scale yang dikembangkan oleh Delaney, Satisfaction with Life Scale (SWLS) yang dikembangkan oleh Diener, Emmons, Larsen, \& Griffin dan WHOQOL-BREF yang dikembangkan oleh WHO. Data dikumpulkan melalui kelompok wirausahawan muda seperti Himpunan Pengusaha Muda Indonesia, Jaringan Pengusaha Muslim Indonesia, dan Junior Chamber International Indonesia. Teknik analisis regresi berganda digunakan dalam analisis data. Dari hasil analisis data, dapat disimpulkan bahwa spiritualitas dan kepuasan hidup berpengaruh signifikan terhadap kualitas hidup pada wirausahawan muda.
\end{abstract}

Kata kunci: kepuasan hidup, kualitas hidup, spiritualitas, wirausahawan muda 


\section{Pendahuluan}

Setiap orang pasti menginginkan kualitas hidup yang baik dan memiliki standar tersendiri mengenai kualitas hidupnya, begitu pun dengan wirausahawan. Menurut Ruggeri (2001) kualitas hidup yang baik merupakan hal yang didambakan oleh setiap orang, namun tidak terdapat satu definisi kualitas hidup yang dapat diterima secara universal. Secara awam individu memberikan gambaran kualitas hidup yang berkaitan dengan pencapaian kehidupan yang ideal atau sesuai dengan yang diinginkan (Kahneman, 1999).

The World Health Organization Quality of Life Assessment Group (selanjutnya disebut sebagai THE WHOQOL GROUP) (1995) menyebutkan kualitas hidup adalah persepsi individu terhadap kehidupannya di masyarakat dalam konteks budaya dan sistem nilai yang ada terkait dengan tujuan, harapan, standar, dan juga perhatian. Individu menilai kondisi kehidupannya saat ini dengan melihat jarak antara posisi kehidupannya saat ini dengan kehidupan yang diinginkan. Kualitas hidup mencakup semua aspek kehidupan. Kalitas hidup memiliki konsep yang sangat luas yang dipengaruhi oleh kondisi fisik, psikologis, tingkat kemandirian, serta hubungan individu dengan lingkungan (Power, 2003). Selain dipengaruhi oleh faktor budaya, harapan, tujuan dan standar, kualitas hidup juga dipengaruhi oleh beberapa faktor demografis seperti gender/ jenis kelamin, usia, pendidikan, pekerjaan, status pernikahan, penghasilan, dan hubungan dengan orang lain (Liao, Fu \& Yi, 2005). Secara garis besar, kualitas hidup meliputi empat domain yang terdiri dari domain fisik, domain psikologis, domain hubungan sosial, dan domain lingkungan (THE WHOQOL GROUP, 1995).
THE WHOQOL GROUP) (1995) membuat studi untuk membangun instrumen universal tentang kualitas hidup. Instrumen yang dibuat oleh THE WHOQOL GROUP ini kemudian diuji cobakan ke berbagai komunitas dan populasi, seperti Schizofrenia (Su, Ng, Yang, Lin, \& ChungYing, 2014), manusia lanjut usia (Liu, $\mathrm{Wu}$, Hao, Gu, Fang, Cai \& Zhang, 2013) , dan pengguna narkotika ( $\mathrm{Fu}$, Tuan, Yen, Wu, Huang, Chen, Li \& Lee, 2013) dengan hasil yang realibel dan valid. Dari beberapa contoh komunitas dan populasi yang disebutkan dalam penelitian sebelumnya mengenai kualitas hidup. Penelitian ini mengambil populasi dan komunitas yaitu wirausaha muda. Glaser, Kerr, dan Kerr (2013) menyampaikan pentingnya wirausahawan sebagai pendorong ekonomi masyarakat. Peran mereka sangat siginifikan dalam pertumbuhan kota (Glaser, Kerr, \& Kerr, 2013). Pada tahun 2017 dan tahun sesudahnya Indonesia akan mengalami bonus demografi yaitu terjadinya lonjakan pertumbuhan usia produktif (Jati, 2015). Isu yang sensitif mengenai bonus demografi adalah penyesuaian lonjakan usia produktif dengan pertumbuhan ekonomi Indonesia khususnya ketersediaan lapangan kerja (Jati, 2015).

Lorenzini (2015) menyebutkan bahwa usia muda yang tidak bekerja akan mempunyai kepuasan hidup yang rendah dan menyebabkan lebih mudah terlibat dalam aksi protes. Pada titik ini, tingkah laku wirausaha dapat menyelesaikan salah satu isu penting yang dihadapi oleh masyarakat Indonesia. Kasali (2010) menyebutkan wirausahawan dapat membantu meningkatkan kepuasan dan kualitas hidup serta membantu meningkatkan perekonomian negara, karena semakin banyak orang yang mampu berwirausaha akan menyebabkan naiknya pendapatan negara. Hal ini menjadi alasan 
bagi penelitian ini untuk mengelaborasi lebih jauh mengenai kualitas hidup dalam komunitas wirausaha, secara khusus yang masih berada di dalam usia produktif. Untuk lebih menajamkan permasalahan maka dalam penelitian ini populasi produktif yang dimaksud lebih spesifik berada pada usia 18-40 tahun. Hal ini disebabkan keumuman organisasi pengusaha pemuda di Indonesia yang berada pada usia 18- 40 tahun (Qamariah, 2016).

Penelitian mengenai kualitas hidup sudah dimulai dengan mencoba mencari alat ukur universal mengenai kualitas hidup (THE WHOQOL GROUP, 1995), dilanjutkan dengan pengujian aspek psikometrik dari alat ukur kualitas hidup (THE WHOQOL GROUP, 1998). Penelitian kualitas hidup tidak terbatas hanya pada individu atau komunitas tetapi juga pada konteks makro seperti isu implemetasi kebijakan publik pada kualitas hidup masyarakat (Bache, 2013). Penelitian ini menceritakan alasan begitu luasnya konteks kualitas hidup dikarenakan saat ini indikator kualitas hidup dan kemajuan bangsa tidak hanya diukur oleh alat ukur pertumbuhan ekonomi tetapi juga oleh kebahagiaan dan kepuasan hidup.

Keterhubungan antara kualitas hidup dan wirausaha tercermin dari keduanya merupakan indikator yang baik untuk melihat pertumbuhan bangsa dan Negara (Bache, 2013, Grine, Fares, \& Meguellati, 2015). Uraian ini menjelaskan alasan penelitian kualitas hidup dengan subjek dan komunitas wirausaha menjadi menarik untuk diteliti.

Sirgy (2012) menjelaskan tentang beberapa variabel penting yang mempunyai hubungan terhadap kualitas hidup. Terdapat faktor penting yang berhubungan dengan kualitas hidup yaitu faktor objektif dan faktor subjektif. Secara objektif faktor demografik, pendapatan, kekayaan, dan kondisi makro mempunyai peran terhadap kualitas hidup. Secara subjektif faktor nilai, kepribadian, emosi, dan kognisi mempunyai peran terhadap kualitas hidup. Pada penelitian ini pemilihan komunitas wirausaha adalah upaya mewakili unsur objektif tentang kualitas hidup. Hal ini dikarenakan wirausahawan mempunyai pengaruh yang cukup besar pada tingkat kekayaan, kesejahteraan, dan pendapatan (Samli, 2009;Bache, 2013). Dalam penelitian Sirgy dijelaskan salah satu faktor subjektif yang cukup penting adalah nilai nilai internal individu seperti religi, spiritualitas, dan kepuasan hidup.

Penelitian yang dilakukan oleh Baker (2003) membuktikan bahwa spiritualitas memberikan kontribusi terhadap kualitas hidup. Berdasarkan hasil penelitian yang dilakukan, pengalaman yang diperoleh sepanjang hidup seseorang akan mempengaruhi kualitas hidup. Pengalaman tersebut juga menjadi dasar dalam memaknai peluang yang diperoleh dalam hidupnya sebagai hasil interaksi dengan lingkungan dan pencapaian keselarasan hidup. Individu yang semakin menua akan cenderung lebih mementingkan urusan spiritualitas mereka (Taylor, 1997). Penelitian lain juga pernah dilakukan oleh Young (2012) pada individu dengan gangguan mental yang menunjukkan bahwa efek positif dari spiritualitas dapat meningkatkan kualitas hidup, karena dengan mendekatkan diri kepada Tuhan maka akan mengurangi stres yang diperoleh dari kehidupan sehari-hari.

Spiritualitas berbeda dengan agama, spiritualitas merupakan konsep yang lebih luas yang bersifat universal dan pribadi sedangkan agama merupakan bagian dari spiritualitas yang terkait dengan budaya dan masyarakat (McEwen, 2003). Individu dikatakan memiliki spiritualitas yang baik jika individu tersebut memiliki 
harapan penuh, optimis, dan berfikir positif (Roper, 2002). Menurut Delaney (2005) spiritualitas adalah fenomena multidimensi yang menghasilkan pengalaman universal, bagian konstruk sosial dan perkembangan individu sepanjang hidup. Spiritualitas seseorang tidak terlepas dari pengaruh faktor-faktor demografis diantaranya tahap perkembangan individu, budaya, keluarga, agama, dan pengalaman hidup yang dialami seseorang (Taylor, 1997).

Dunia wirausaha menimbulkan ketertarikan tersendiri bagi orang-orang yang berkeinginan mandiri secara finansial, memperoleh kepuasan, dan kualitas hidup yang lebih baik (Suharyadi, 2012). Kuratko, Hornby, dan Naffziger (1997) menemukan bahwa wirausahawan mendapatkan kepuasan lebih dari usahanya sendiri dibandingkan saat mereka masih menerima gaji/upah dari orang lain. Kepuasan dari usaha yang mereka jalankan menurut penelitian VandeHeuvel dan Wooden (1997) akan berpengaruh terhadap kepuasan hidup seseorang. Dengan berwirausaha, maka peluang untuk membuktikan kemampuan diri, menggunakan keahliannya dalam bekerja, serta mendapatkan pengakuan publik bila mampu mengelola usahanya dengan baik. Menurut penelitian Finnie \& La Portie (2002), kebutuhan akan keberhasilan mendorong seseorang untuk mencari peluang berwirausaha dengan harapan dapat memperoleh kepuasan yang lebih besar dalam bekerja. Penelitian yang dilakukan oleh Suyatini (2004) menunjukkan bahwa kepuasan hidup berwirausaha memiliki pengaruh yang positif terhadap kualitas hidup wirausahawan. Kepuasan hidup sebagai tingkatan perilaku individu terhadap kualitas hidup mereka yang dapat disamakan dengan kebahagiaan (Pavot \& Diener, 2008).

Kepuasan hidup merupakan penilaian secara kognitif mengenai seberapa baik dan memuaskan hal-hal yang sudah dilakukan individu dalam kehidupannya secara menyeluruh (Diener, Emmons, Larsen, \& Griffin, 1985; Diener, Ingleheart, \& Tay, 2012). Individu yang memiliki kepuasan hidup yang tinggi adalah individu yang memiliki tujuan penting dalam hidupnya dan berhasil untuk mencapai tujuan tersebut Individu dengan kepuasan hidup yang tinggi merasa bahwa hidup mereka bermakna dan mempunyai tujuan dan nilai yang penting bagi individu bersangkutan. Menurut Iverson dan Maguire (2000) menemukan faktor-faktor yang mempengaruhi kepuasan hidup seseorang yaitu berkaitan dengan pekerjaan, pribadi, lingkungan, dan masyarakat. Hubungan antara kepuasan kerja dan kepuasan hidup adalah penting karena kepuasan dalam bekerja menjadi salah satu faktor penyebab terwujudnya kepuasan hidup seseorang (VandeHeuvel \& Wooden, 1997). Untuk mempertegas batasan kepuasan hidup maka kepuasan hidup terdiri atas lima aspek yaitu keinginan untuk mengubah hidup, perasaan puas terhadap kehidupan masa sekarang, masa lalu, dan masa yang akan datang, serta bagaimana penilaian orang lain terhadap individu yang bersangkutan (Diener, Emmons, Larsen, \& Griffin, 1985; Diener, Ingleheart,\& Tay, 2012).

Penelitian sebelumnya menemukan bahwa kualitas hidup yang baik menjadi tujuan utama bagi para wirausahawan (Lu \& Pan, 2009). Di dalam penelitian ini, Lu \& Pan (2009) menemukan faktor kepuasan hidup sebagai hal yang mempunyai pengaruh terhadap kualitas hidup wirausahawan. Hal senada juga ditemukan oleh Liao, Fu, \& Yi (2005) dan Fadda \& Jiron (1999) bahwa faktor kepuasan hidup mempunyai pengaruh terhadap kualitas hidup wirausahawan, walau hal ini juga dipengaruhi oleh 
faktor lain seperti konteks budaya, sistem masyarakat, status pernikahan, dan tingkat pendidikan. Sedangkan menurut Rogala (2014) bahwa kualitas hidup merupakan hal yang berkaitan dengan kebutuhan individu itu sendiri.

Sebuah penelitian yang dilakukan oleh Dash \& Kaur (2012) di Orisa, India menemukan bahwa dari pencapaian yang diperoleh dari berwirausaha tersebut, dapat menimbulkan kepuasan tersendiri terhadap hidupnya. Beberapa fakta mendukung bahwa kualitas hidup sangat didukung oleh spiritualitas dan kepuasan hidup. Oleh karena itu, peneliti bermaksud mengkaji kualitas hidup pada usia produktif, khususnya pada wirausahawan muda yang dilihat dari pengaruh sisi spiritualitas dan kepuasan hidup. Dengan demikian, dalam penelitian ini dikaji ke dalam tiga hipotesis yaitu:

H1: Spiritualitas berpengaruh terhadap quality of life pada wirausahawan muda.

H2: Life satisfaction berpengaruh terhadap quality of life pada wirausahawan muda.

H3: Spiritualitas dan life satisfaction berpengaruh pada quality of life pada wirausahawan muda.

\section{Metode Penelitian}

Penelitian ini menggunakan metode kuantitatif untuk mengkaji peran atau pengaruh variabel Life Satisfaction dan spiritualitas dengan kualitas hidup pada wirausaha muda. Subjek dalam penelitian ini merupakan wirausahawan muda yang tersebar hampir di seluruh Indonesia (20-40 tahun) sebanyak 384 subjek. Kuesioner disebar melalui kelompok wirausahawan muda seperti Himpunan Pengusaha Muda Indonesia, Jaringan Pengusaha Muslim Indonesia, dan Junior Chamber International Indonesia. Menurut Martono (2012), penentuan jumlah subjek menggunakan perhitungan Rumus Lemeshow untuk populasi yang tidak diketahui, sehingga diperoleh 384 subjek. Pemilihan menggunakan Rumus Lemeshow karena belum ada data yang tepat dan akurat mengenai persebaran wirausaha muda sehingga asumsi populasi adalah tidak diketahui. Persebaran subjek dapat dilihat pada tabel berikut:

Tabel. 1 Data Persebaran Subjek

\begin{tabular}{llcc}
\hline Keterangan & & Frekuensi & $\%$ \\
\hline Usia & $16-20$ & 99 & 25.78 \\
& $21-25$ & 217 & 56.51 \\
& $26-30$ & 27 & 7.03 \\
& $31-35$ & 32 & 8.33 \\
& $36-40$ & 9 & 2.34 \\
\hline Agama & Islam & 344 & 89.58 \\
& Katolik & 15 & 3.91 \\
& Protestan & 12 & 3.13 \\
& Budha & 3 & 0.78 \\
\hline Penghasilan & $<5,000,000$ & 91 & 23.70 \\
perbulan & $5,000,000-10.000 .000$ & 203 & 52.86 \\
& $>10,000,000$ & 90 & 23.44 \\
\hline \multicolumn{4}{c}{ Sumber: Hasil Olah Data, 2016} \\
\end{tabular}

Teknik pengumpulan data dengan menggunakan kuesioner yang terdiri dari pertanyaan mengenai data demografis subjek, dan item-item pertanyaan yang diadaptasi dengan proses one way translation, diantaranya Spirituality Scale yang dikembangkan oleh Delaney, (2005) Satisfaction with Life Scale (SWLS) yang dikembangkan oleh Diener, Emmons, Larsen, \& Griffin (1985) dan WHOQOLBREF yang dikembangkan oleh WHO (Skevington, Lotfy \& O'Connell, 2004). Skala kualitas hidup terdiri atas 26 item yang mengungkap kualitas hidup dari lima domain yaitu fisik, psikologis, hubungan sosial, lingkungan dan umum. Adapun contoh itemnya antara lain "Apakah Anda memiliki energi yang cukup untuk menjalani kehidupan sehari-hari?"," Sejauh mana 
Anda menikmati hidup?", “Seberapa puaskah Anda dengan hubungan pribadi yang Anda jalani?", " Sejauh mana Anda merasa aman dalam kehidupan sehari-hari Anda?.” Bagaimana Anda menilai kualitas hidup Anda?".

Skala spiritaualitas digunakan untuk mengukur spiritualitas yang berjumlah 22 item . Adapun contoh itemnya antara lain: "Saya merasa menemukan makna dalam pengalaman hidup saya", "Saya dapat menerima rasa cinta dari orang lain"," Saya percaya pada kekuatan yang lebih tinggi (higher power)/ Universal Intelligence". Untuk mengukur kepuasan hidup (life satisfaction) digunakan skala Satisfaction with Life Scale (SWLS) yang terdiri dari 5 item. Alat ukur ini terdiri atas lima aspek yang dijadikan item pernyataan dan bersifat favorable. Contoh Item skala kepuasan hidup, antara lain:" Dalam banyak hal, saya merasa bahwa hidup saya mendekati hidup yang ideal", "Saya merasa bahwa kondisi hidup saya sangat baik", "Saya merasa puas dengan hidup saya", "Sejauh ini saya selalu mendapatkan hal-hal penting yang saya inginkan dalam hidup', Jika saya bisa menjalani kehidupan saya, saya hampir tidak akan mengubah apa pun dalam hidup saya'.

Skala ukur yang memiliki reliabilitas yang baik apabila hasil perhitungan Cronbach's Alpha berada antara 0.700.95 (Devellis, 2003; Tavakol \& Dennick, 2011). Sedangkan untuk uji validitas, suatu item dikatakan valid apabila skor korelasi item-total $\left(\mathrm{r}_{\mathrm{it}}\right)$ lebih besar daripada skor $\mathrm{r}_{\text {tabel }}$ (Carmines \& Zeller, 1979;). Hasil Uji reliabilitas dan validitas skala yang digunakan pada penelitian ini adalah sebagai yang tertera di tabel 2:
Tabel. 2 Uji reliabilitas dan validitas skala

\begin{tabular}{ccccc}
\hline Variabel & $\begin{array}{c}\text { Reliabil- } \\
\text { itas }\end{array}$ & $\begin{array}{c}\text { Keteran- } \\
\text { gan }\end{array}$ & Validitas & $\begin{array}{c}\text { Keteran- } \\
\text { gan }\end{array}$ \\
\hline Quality of & .877 & Reliabel & $0.062-$ & $3,4,9$ tdk \\
Life & & & 0.728 & valid \\
Spiritual- & .880 & Reliabel & $0.406-$ & Semua \\
itas & & & 0.712 & item valid \\
Life Sat- & .818 & Reliabel & $0.664-0$. & Semua \\
isfaction & .818 & & 839 & item valid \\
\hline
\end{tabular}

Data yang terkumpul dianalisis dengan menggunakan uji validitas dan reliabilitas untuk mengetahui kualitas data penelitian . Uji hipotesis dilakukan dengan menggunakan uji regresi sederhana dan uji regresi berganda. Data dianalisis dengan bantuan software SPSS 20 for Windows.

\section{Hasil dan Pembahasan}

Analisis Variabel Spiritualitas dengan Kualitas Hidup

Tabel.3 Analisis Regresi Sederhana Quality of Life dan Spiritualitas

\begin{tabular}{lcc}
\hline Variabel & $\mathrm{R}^{2}$ & $\mathbf{B}$ \\
Spiritualitas & .281 & .530 \\
\hline
\end{tabular}

Correlation is significant at the 0.05

Dari hasil pengujian tabel 3 didapatkan bahwa hipotesa 1 diterima, bahwa variabel spiritualitas mempunyai pengaruh terhadap variabel kualitas hidup (Quality of life). Berdasarkan hasil uji regresi antara quality of life dengan spiritualitas diperoleh bahwa prediktor spiritualitas menjelaskan $28.1 \%$ dari varian quality of life $\left(\mathrm{R}^{2}=.281, \mathrm{~F}(1\right.$, $382)=149.120, p<0.05)$, dan sisanya dipengaruhi oleh variabel lain.

Hasil ini menguatkan eksplorasi kualitatif yang dilakukan oleh Grine, Fares, dan Meguellati (2015) mengenai spiritualitas dan wirusahawan. Ulasan ini menceritkan bahwa wirausahawan yang mempraktikan aktivitas keagamaan 
dan spiritualitas mampu meningkatkan kebahagiaan dan kualitas hidup mereka. Hal yang sama terjadi di dalam ulasan Grine, Fares dan Meguellati (2015) dengan penelitian ini adalah tentang kesamaan subjek yang mayoritas beragama Islam. Di dalam subjek penelitian ini terdapat mayoritas wirausahawan beragama Islam yaitu sebanyak 344 orang $(89.58 \%)$.

Di dalam spiritualitas Islam, tidak adanya perbedaan signifikan antara religiusitas dan spiritualitas, hal ini menyebabkan subjek dalam hal ini wirausahawan yang mempraktikan secara teratur aktivitas religiusitas akan meningkatkan spiritualitas (Grine, Fares, \& Meguellati, 2015). Ulasan ini menyebutkan aktivitas religiusitas yang dimaksud dalam spiritualitas Islam adalah sholat, berpuasa, berderma, dan melakukan haji. Dari hasil penelitian ini, yang mempunyai kesamaan subjek dengan mayoritas beragama Islam, penelitian ini menguatkan hasil bahwa aktivitas religiusitas yang regular dapat meningkatkan kualitas hidup pada wirausahawan.

Penelitian ini juga menguatkan bahwa variabel spiritualitas mempunyai pengaruh dalam kualitas hidup. Shade dan Flack (2015) menyebutkan pentingnya spiritualitas dikarenakan dapat menjadi sumber daya dan penggerak utama. Hal yang lebih spesifik ditemukan oleh Sherman, Randall, dan Kauanui (2015) bahwa wirausahawan yang mempunyai nilai spiritualitas dalam usaha dan mempraktikan aktivitas religius secara teratur akan mendapatkan kebahagiaan, kesehatan, kesenangan, produktivitas dan ketahanan terhadap stress yang lebih baik. Faktor kebahagiaan, kesehatan, kesenangan, produktivitas, dan ketahanan terhadap stress adalah beberapa faktor yang muncul dalam faktor anteseden kualitas hidup (Sirgy, 2012).
Balog, Baker, dan Walker (2013) menyebutkan bahwa wirausaha mempunyai pemaknaan yang mendalam terhadap aktitas usaha yang dilakukannya. Dalam ulasan ini wirusaha menyebutkan aktivtias usaha sebagai panggilan hidup. Hal ini disebabkan wirausaha mencari makna yang mendalam terhadap aktivitas usaha yang dilakukannya. Dalam ulasan ini pencarian makna yang mendalam akan sangat dipengaruhi oleh variabel spiritual. Balog, Baker, dan Walker (2013) menyebutkan variabel spiritual dibutuhkan oleh wirausahawan sebagai sarana yang akan menjadikan hidup seimbang dan meningkatkan kualitas hidup. Hasil dari penelitian ini menguatkan bahwa variabel spiritualitas mempunyai pengaruh terhadap kualitas wirausaha. Hal yang baru adalah hal ini tidak hanya terjadi pada wirausahawan yang sudah berusia tua seperti yang disampaikan dalam penelitian Taylor (1997) tetapi juga terjadi pada komunitas wirausahawan muda.

Tabel. 4 Analisis Regresi Sederhana Quality of Life dan Life Satisfaction

\begin{tabular}{lcc}
\hline Variabel & $\mathrm{R}^{2}$ & B \\
Life Satisfaction & .306 & .553 \\
\hline
\end{tabular}

Correlation is significant at the 0.05

Dari hasil pengujian tabel 4 didapatkan bahwa hipotesa 2 diterima, bahwa variabel kepuasan hidup (Life Satisfaction) mempunyai pengaruh terhadap variabel kualitas hidup (Quality of life). Berdasarkan hasil uji regresi antara quality of life dengan life satisfaction diperoleh bahwa prediktor life satisfaction menjelaskan $30.6 \%$ dari varian quality of life $\left(\mathrm{R}^{2}=.306, \mathrm{~F}(1,382)=\right.$ $168.528, \mathrm{p}<0.05)$, dan sisanya dipengaruhi oleh variabel lain. Hasil dari penelitian ini sejalan dengan penelitian Dash dan Kaur (2012) menjelaskan bahwa kepuasan hidup 
wirausahawan terhadap hasil usahanya memberikan kontribusi berarti terhadap kualitas hidupnya. Di dalam ulasannya kepuasan hidup ini muncul dari keberhasilan wirusahawan dalam mencapai prestasi usaha.

Kuratko, Hornby, dan Naffziger (1997) menguatkan bahwa pekerjaan yang memberikan kepuasan akan meningkatkan kualitas hidup. Berdasarkan hasil penelitian wirausahawan melihat profesi wirausaha sebagai sarana untuk mencapai tujuan hidup yang memberikan kepuasan hidup dan peningkatan kualitasn hidup. Penelitian ini juga menemukan bahwa faktor yang mendorong kepuasan hidup wirausahawan adalah keuntungan yang diperolah dari usahanya sendiri. Para wirausahawan merasa profesi wirausaha memberikan kepuasan hidup yang lebih baik dibandingkan saat menerima gaji ketika masih bekerja. VandeHeuvel dan Wooden (1997) memberikan gambaran hal hal yang dipersepsi oleh wirausahawan sebagai faktor peningkatan kualitas hidup yaitu pertama kebebasan dan kemandirian dalam mengatur waktu bekerja, kedua kemerdekaan dalam mengatur bentuk pekerjaan, dan ketiga penghasilan yang lebih memadai dan mencukupi.

Penelitian ini mempunyai temuan yang baru dikarenakan mengukur secara terpisah antara kepuasan hidup dengan spiritualitas. Penelitian terdahulu telah memberikan gambaran bahwa spiritualitas mempunyai pengaruh terhadap kepuasan hidup (Veerasamly, Sambasivan, \& Kumar, 2014) dengan didahului faktor religiusitas mempunyai pengaruh terhadap spiritualitas. Pada temuan ini faktor kepuasan hidup dapat menjadi prediktor secara terpisah pada kualitas hidup.
Tabel.5 Analisis Regresi Berganda dalam Memprediksi Quality of Life Analisis Regresi dalam Memprediksi Quality of Life $(\mathrm{n}=384)$

\begin{tabular}{llc} 
Variabel & $\Delta \mathrm{R}^{2}$ & $\mathrm{~B}$ \\
\hline Step 1 & .281 & \\
Spiritualitas & & .530 \\
Step 2 & .439 & \\
Spiritualitas & & .387 \\
Life & & .423 \\
Satisfaction & & \\
\hline
\end{tabular}

Correlation is significant at the 0.05 level

Dari hasil pengujian tabel 5 didapatkan bahwa hipotesa 3 diterima, bahwa variabel spiritualitas dan kepuasan hidup (Life Satisfaction) mempunyai pengaruh terhadap variabel kualitas hidup (Quality of life). Penelitian ini menggunakan analisis regresi berganda untuk menguji pengaruh spiritualitas dan life satisfaction terhadap quality of life. Hasil uji regresi berganda menyatakan bahwa dua prediktor memiliki pengaruh sebesar $43.9 \%$ terhadap kualitas hidup (Quality of life) $\left(\mathrm{R}^{2}=.439, \mathrm{~F}(2,381)\right.$ $=149.156, \mathrm{p}<0.05)$, dan sisanya variebal kualitas hidup dipengaruhi oleh variabel lain, selain spiritualitas dan kepuasan hidup (life satisfaction).

Tujuan dari penelitian ini adalah untuk mengetahui seberapa besar peran spiritualitas dan life satisfaction terhadap quality of life pada wirausahawan muda. Hasil penelitian ditemukan bahwa sebesar 43.9\% secara bersama-sama spiritualitas dan life satisfaction memiliki pengaruh terhadap quality of life (kualitas hidup) wirausahawan muda. Penelitian ini juga menemukan bahwa variabel kepuasan hidup (life satisfaction) memiliki pengaruh yang lebih besar yaitu sebesar 30.6\% daripada variabel spiritualitas yang sebesar $28.1 \%$. 
Analisis dari lebih besarnya variabel kepuasan hidup dibandingkan variabel spiritualitas dapat dilihat dari demografi sampel penelitian yang mayoritas berada pada usia 21-25 tahun $(56,51 \%)$. Usia yang relatif muda dapat menyebabkan wirausahawan lebih mengejar kepuasan hidup daripada spiritualitas. Analisis ini didukung oleh penelitian Taylor (1997) yang menceritakan semakin bertambah usia, semakin tinggi kesadaran dan pencarian spiritualitas. Peter dan Schukert (2014) menemukan kecenderungan bahwa semakin bertambahnya usia, para wirausahawan semakin membutuhkan keseimbangan hidup dalam menjalakan usaha. Wirausahawan tetap mengingkan usahanya bertumbuh, namun juga merasa penting menjalankan usaha secara seimbang (Peter \& Schukert, 2014). Salah satu yang berperan menjalankan keseimbangan hidup adalah spiritualitas (Baker, 2003).

Penelitian ini menemukan bahwa walau variabel kepuasan hidup (life satisfaction) lebih besar, namun angkanya tidak berjarak terlalu jauh dari variabel spiritualitas. Hasil ini dapat memperlihatkan bahwa kedua variabel mempunyai peran dalam kualitas hidup. Analisis regresi berganda memperlihatkan ketika dua variabel ini diukur secara bersamaan terhadap variabel kualitas hidup terdapat kenaikan angka prediktor lebih besar dibandingkan kedua variabel diukur secara terpisah. Hal ini menguatkan bahwa wirausahawan membutuhkan kepuasan hidup dalam menjalankan usaha sekaligus meningkatkan nilai spiritualitas (Balog, Baker, \& Walker, 2013; Benefiel, Fry, \& Geigle, 2014; Sherman, Randall, \& Kauanui, 2015).

Penelitian tentang kualitas hidup memperlihatkan bahwa ada faktor internal seperti agama (religi) dan faktor eksternal seperti globalisasi dan pertumbuhan ekonomi negara (Sandikci, Peterson, Ekici, \& Simkins, 2015). Hasil Penelitian ini berfokus pada faktor internal; dalam hal ini spiritualitas dan kepuasan hidup; yang mempengaruhi kualitas hidup pada wirausahawan muda. Hasil dari penelitian ini menemukan bahwa faktor spiritualitas bisa menjadi prediktor baik berdiri sendiri atau bersama dengan faktor lain.

Penelitian ini memperkuat bahwa wirausahawan membutuhkan variabel spiritualitas dalam melakukan usahanya baik berdiri sendiri atau bersama dengan faktor lain. Sudah ada pendapat yang memperlihatkan preposisi model variabel spiritualitas dengan faktor lain sebagai variabel yang dibutuhkan wirausahawan (Godwin, Neck, \& D'Intino, 2016) namun hal ini masih menjadi model konseptual. Penelitian ini memberikan kontribusi empirik pengaruh variabel spritualitas, baik berdiri sendiri atau bersama faktor kepuasan hidup terhadap kualitas hidup dalam populasi wirausahawan muda.

Penelitian ini memperkuat basis teoritis tentang spiritualitas di dunia kerja khususnya pada profesi wirausahawan. Studi terdahulu memperlihatkan bahwa spiritualitas dan religiusitas mempunyai peran dan kontribusi di dunia kerja (Benefiel, Fry, \& Geigle, 2014). Ulasan yang dilakukan Benefiel, Fry, dan Geigle (2014) memperlihatkan bahwa variabel spiritualitas dan religusitas bisa dikaji dan dikembangkan secara terpisah atau intergratif. Ada beberapa penelitian terdahulu yang mengintegrasikan antara aktivitas religusitas dan spiritualitas pada wirausaha dan dunia kerja (Veerasamy, Sambasivan, \& Kumar, 2014; Sherman, Randall, \& Kauanai, 2015). Penelitian ini membatasi hanya mengkaji spiritualitas. Penelitian berikutnya dapat meneliti tentang aktivitas religusitas atau religi terhadap 
kualitas hidup.

Penelitian ini juga menambahkan kontribusi tentang pengukuran kualitas hidup ditinjau dari sisi aspek sosial dan lingkungan. Hal ini memperkuat pendapat yang memberikan tinjauan bahwa kualitas hidup tidak hanya diukur dari aspek ekonomi tetapi juga aspek sosial dan lingkungan (Samli, 2009; Bache, 2013; Tay, Kuykendall, \& Diener, 2015).

Penelitian ini juga tidak membahas faktor eksternal yang mempengaruhi kualitas hidup. Penelitian ini hanya berfokus pada faktor internal yang mempengaruhi kualitas hidup khususnya spiritualitas dan kepuasan hidup. Penelitian selanjutnya dapat melihat lebih jauh kontribusi faktor eksternal dan faktor internal terhadap kualitas hidup.

\section{Simpulan}

Penelitian ini memberikan gambaran bahwa variabel spiritualitas dan kepuasan hidup mempunyai pengaruh terhadap kualitas hidup. Variabel spiritualitas dan kepuasan hidup dapat mempengaruhi variabel kualitas hidup secara independen atau bersama sama. Angka prediktif yang didapat dari penelitian ini menunjukkan jika disandingkan antara spiritualitas dan kepuasan hidup secara bersama sama akan mendapatkan angka prediktif yang lebih tinggi. Dari penelitian ini menunjukkan bahwa kedua variabel (spiritualitas dan kepuasan hidup) mempunyai peran yang signifikan bagi kualitas hidup wirausahawan khususnya wirausahawan muda. Ini menunjukkan bahwa aktivitas usaha tidak hanya soal pertumbuhan ekonomi dan keuntungan semata tetapi juga pertumbuhan internal wirausahawan itu sendiri.

\section{Daftar Pustaka}

Bache, I. (2013). Measuring quality of life for public policy: an idea whose time has come? Agenda-setting dynamics in the European Union. Journal of European Public Policy, 20 (1), 21-38, DOI: 10.1080/13501763.2012.699658

Baker, D.C. (2003). Studies of the inner life: The impact of spirituality on quality of life. Journal of Quality of Life Research, 12 (1), 51-57.

Balog, A. M., Baker, L. T., \& Walker, A.G. (2013). Religiosity and spirituality in entrepreneurship: a review and research agenda. Journal of Management, Spirituality \& Religion, doi: 10.1080/14766086.2013.836127.

Benefiel, M., Fry, L. W., \& Geigle, D. (2014). Spirituality and religion in the workplace: history, theory, and research. Psychology of Religion and Spirituality, doi: 10.1037/a0036597

Carmines E.G. \& Zeller, R.A. (1979). Reliability and Validity Assessment: Quantitative Applications in the Social Sciences. London: Sage.

Devellis, R. (2003). Scale Development: Theory and Applications: Theory and Application.Thousand Oaks: Sage.

Diener, E., Emmons, R.A., Larsen, R.J, \& Griffin, S. (1985) The Satisfaction With Life Scale. Journal of Personality Assessment, 49 (1), 71-75.

Diener, E., Inglehart, R., \& Tay, L. (2012). Theory and Validity Of Life Satisfaction Scales. Social Indicator Research.

Dash, M., \& Kaur. K. (2012). Youth Entrepreneurship as a Way of Boosting 
Indian Economic Competitiveness: A Study of Orissa India: International Review of Management and Marketing, 2 (1).

Delaney, C. (2005). The Spirituality Scale Development And Psychometric Testing of Holistic Instrument to Assess the Human Spiritual Dimension. Journal of Holistic Nursing, 23(2), 146-167.

Fadda, G. \& Jiron, P. (1999). Quality of Life and Gender: A Methodology for Urban Research. Environment and Urbanization, 11(2), 1-13.

Finnie, R. \& Laporte, C. (2002). Setting up Shop: Self-Employment among Canadian College and University Graduates. Industrial Relations.

Fu, T. S., Tuan, Y., Yen, M., Wu, W., Huang, C., Chen, W., Li C. R., \& Lee, T. S.,(2013). Psychometric properties of the World Health Organization quality of life assessment - brief in methadone patients: a validation study in northern Taiwan. Harm Reduction Journal.

Glaeser, E. L., Kerr, S.R., \& Kerr, W. R. (2013). Entrepreneurship and Urban Growth: An Empirical Assessment with Historical Mines. Review of Economics and Statistics, doi:10.1162/ REST_a_00456

Goodwin, C. J. (2010). Research in Psychology Methods and Design; Sixth Edition. John Wiley \& Sons

Goodwin, J. L., Neck, C. D., \& D'Intino, R.S. (2016). Self-leadership, spirituality, and entrepreneur performance: a conceptual model. Journal of Management, Spirituality \& Religion, doi: $10.1080 / 14766086.2015 .1122546$

Grine, F., Fares, D., \& Meguellati, A. (2015). Islamic spirituality and entrepreneurship: A case study of women entrepreneurs in Malaysia. The Journal of Happiness \& WellBeing, 3(1), 41-56

Hahn, V. C., Frese, M., Binnewies, C., \& Schmitt, A. (2012). Happy and Proactive? The Role of Hedonic and Eudaimonic Well-Being in Business Owners' Personal Initiative. Entrepreneurship Theory and Practice, doi: 10.1111/j.15406520.2011.00490.x

Jati, W. R. (2015). Bonus Demografi Sebagai Mesin Pertumbuhan Ekonomi: Jendela Peluang Atau Jendela Bencana Di Indonesia? Jurnal Populas, 23 (1), 1-19

Iverson, R.D. \& Maguire, C. (2000). The Relationship between Job and Life Satisfacton: Evidence from a Remote mining Community. Human Relation, 53(6), 807-839.

Kahneman, E., Diener, \& Schwarz. (1999). Causes and Correlates of Happiness, Well-being: The Foundations of Hedonic Psychology. New York: Russell Sage Foundation.

Kasali, R. (2010). Wirausaha Muda Mandiri. Jakarta: Gramedia Pustaka Utama.

Kuratko, D.F., Hornby, J.S. \& Naffziger, D.W. (1997). An Examination of Owner's Goals in Sustaning Entrepreneurship. Journal of Small Business Management, 35(1), 24-33.

Liao, P., Fu, Y., \& Yi, C. (2005). Perceived Quality of Life in Taiwan and Hong Kong: AN Intra-Culture Comparison. 
Journal of Happiness Studies, 6(1), 43-67.

Liu, R., Wu, S., Hao, Y., Gu, J., Fang, J., Cai, N., \& Zhang, J.(2013). The Chinese version of the world health organization quality of life instrumentolder adults module (WHOQOLOLD): psychometric evaluation. Health and Quality of Life Outcomes, 11: 156.

Lorenzini, J. (2015). Subjective WellBeing and Political Participation: A Comparison of Unemployed and Employed Youth. Journal Of Happiness Studies, 16:381, doi:10.1007/s10902-014-9514-7

Lu, M., \& Pan, H. (2009). GovernmentEnterprise Connection Entrepreneur and Private Enterprise Development in China. Peking University Press

Martono, N. (2012). Metode Penelitian Kuantitatif. Jakarta: Rajawali Pers.

McEwen, W. (2003). Analysis of spirituality contenst in nursing textbooks. Journal of Nursing Education, 43(1), 20-30.

Neuman, W. L. (2014). Social Research Methods: Qualitative and Quantitative Approaches, seventh edition. Pearson Education Limited.

Pavot, W. \& Dinner. (2008). The Satisfaction with Life Scale and the emerging construct of life satisfaction. The Journal of Positive Psychology, 3(2), 137-152.

Peters, M., \& Schuckert, M. (2014). Tourism entrepreneurs' perception of quality of life: an explorative study. Tourism Analysis, 19, 731-740, DOI: 10.3727 /108354214X14146846679484
Power, M. (2003). Development of a common instrument for quality of life. Dalam Nasikov, A. \& Gudex, C. (Ed.), EUROHIS: Developing a Common Instrument for Health Survey. The Netherlands: IOS PRESS.

Rogala, P. (2014, Mei). Evaluation of the Subjective Quality of Life: PolishGerman Borderline Case. Paper presented at International Quality Conference, University of Kragujevac.

Roper, N. (2002). Prinsip-prinsip keperawatan. Yogyakarta: Yayasan Essentia Medica.

Qamariah, P. (2016). Strategi humas himpunan pengusaha muda Indonesia dalam menjaring anggota baru di kalangan pengusaha muda di Samarinda. eJournal lmu Komunikasi, 4 (1): 254-268, dari http://ejournal. ilkom.fisip-unmul.ac.id/site/wpcontent/uploads/2016/03/Jurnal\%20 Putri\%20Qamariah\%20fix\%20(0303-16-06-09-22).pdf

Ruggeri, M., Bisoffi, G., Fontecedro, L., \& Warner, R. (2001). Subjective and Objective Dimensions of Quality of Life in Psychiatric Patients: a Factor Analytical Approach: The South Verona Outcome Project 4. British Journal of Psychiatry, 178(3), 268275.

Samli, A. C. (2009). Entrepreneurship economic development and quality of life in third-world countries. Applied Research Quality Life, doi 10.1007/ s11482-009-9056-z

Sandikci, O., Peterson, M., Ekici, A., \& Simkins, T. (2015). Development and quality of life in turkey: how globalization, religion, and economic 
growth influence individual well-being. Journal of Macromarketing, 1-17, doi: $10.1177 / 0276146715608919$

Sherman, C. L., Randall, C., \& Kauanui, S. K. (2015): Are you happy yet? Entrepreneurs' subjective wellbeing. Journal of Management, Spirituality \& Religion, doi: 10.1080/14766086.2015.1043575

Sirgy, M.J. (2012). The Psychology of Quality of Life Hedonic Well-Being, Life Satisfaction, and Eudaimonia: Second Edition. Social Indicator Research.

Skevington, S.M., Lotfy, M. \& O'Connell, K.A. (2004). The World Health Organization's WHOQOLBREF quality of life assessment: Psychometric properties and results of the international field trial A Report from the WHOQOL Group. Quality of Life Research, 13: 299-310.

Su, C., Ng, H., Yang, A., \& Lin, C. (2014). Psychometric evaluation of the Short Form 36 Health Survey (SF-36) and the World Health Organization Quality of Life Scale Brief Version (WHOQOL-BREF) for patients with schizophrenia. Psychological Assessment, 26(3), 980-989.

Suharyadi, dkk. (2012). Kewirausahaan: Membangun Usaha Sukses Sejak Usia Muda. Jakarta: Salemba Empat.

Tavakol, M. \& Dennick, R. (2011). Making sense of Cronbach's Alpha. International Journal of Medical Education, (2), 53-55.

Taylor, B. (1997). Earthen Spirituality or Cultural Genocide?: Radical Environmentalism's Appropriation of Native American Spirituality. in Religion, 27(2), 183-215.

Tay, L., Kuykendall, L., \& Diener, E. (2015). Satisfaction and Happiness - The Bright Side of Quality of Life. Dalam Glatzer, W., Camfield, L., Møller, V., \& Rojas, M., (Ed.), Global Handbook of Quality of Life Exploration of WellBeing of Nations and Continents. Springer.

THE WHOQOL GROUP. (1995). The World Health Organization Quality Of Life Assessment (Whoqol): Position Paper From The World Health Organization. Social Science and Medicine.

THE WHOQOL GROUP. (1998). The World Health Organization Quality Of Life Assessment (Whoqol): Development And General Psychometric Properties. Social Science and Medicine.

VandeHeuvel, A., \& Wooden, M. (1997). Self Employed Contractors and Job Satisfaction. Journal of Small Business Management, 35(3), 11-20.

Veerasamy, C., Sambasivan, M., \& Kumar, N. (2014). Life satisfaction among healthcare volunteers in malaysia: role of personality factors, volunteering motives, and spiritual capital. Voluntas, doi 10.1007/s11266-0149437-2

Young, K.W. (2012). Positive effects of Spirituality on Quality of life for People with Severe Mental Illness. International Journal of Psychosocial Rehabilitation, 6(2), 62-77. 